\title{
Tanggap Pertumbuhan dan Hasil Tanaman Jagung terhadap Waktu Tanam yang Berbeda
}

\author{
The Response of Growth and Yield of Maize to Different Sowing Date
}

\author{
Maria Imelda Humoen ${ }^{1}$, Sudirman Yahya ${ }^{2 *}$, dan Supijatno ${ }^{2}$ \\ ${ }^{1}$ Program Studi Agronomi dan Hortikultura, Sekolah Pascasarjana, Institut Pertanian Bogor \\ ${ }^{2}$ Departemen Agronomi dan Hortikultura, Fakultas Pertanian, Institut Pertanian Bogor \\ (IPB University), Jl. Meranti, Kampus IPB Darmaga, Bogor 16680, Indonesia
}

Diterima 11 Mei 2020/Disetujui 20 Juli 2020

\begin{abstract}
Determination of the appropriate sowing date can reduce the negative impact of the low water availability and solar radiation in the growth phase and yield of maize. This research aimed to (1) determine the effective sowing date to get the optimal solar radiation, water, and yields, (2) determine the appropriate varieties for the sowing date to optimize the utilization of radiation and water. The experiment was conducted at the Agricultural Technology Assessment Station (BPTP) Naibonat, NTT from February to July 2019. The three-factor factorial experiment using a split-split plot design. The main plot, namely three sowing dates were 26 February 2019, 12 March 2019, and 26 March 2019. The subplots, namely three varieties of maize consisted of Pena muti m'naes, Lamuru, and Pioneer-36. The sub-sub plot, namely 2 levels of watering consisting of not watered and watered. The results showed that the sowing date of 12 March 2019, was the appropriate sowing date and corresponding with the level of availability of water and solar radiation with more efficient use and higher levels of solar radiation interception to provide Pioneer-36 production of 8.47 tons $\mathrm{ha}^{-1}$, which was better than the production of Local and Lamuru varieties of maize at other sowing dates. This is supported by the synchronized responses of both source capacity (leaf area) and sink capacity (ear size).
\end{abstract}

Keywords: leaf area index, production, varieties, watering

\section{ABSTRAK}

Penentuan waktu tanam yang tepat dapat mengurangi dampak negatif dari rendahnya ketersediaan air dan radiasi matahari pada fase pertumbuhan dan hasil tanaman jagung. Penelitian ini bertujuan (1) menentukan waktu tanam dan varietas jagung yang dapat menyelaraskan pemanfaatan radiasi matahari dan ketersediaan air (2) mengetahui pengaruh penyiraman terhadap pertumbuhan dan hasil tanaman jagung. Lokasi penelitian bertempat di Balai Pengkajian Teknologi Pertanian (BPTP) Naibonat, NTT pada bulan Februari-Juli 2019. Percobaan faktorial tiga faktor menggunakan rancang split-split plot. Petak utama waktu penanaman terdiri dari tanggal 26 Februari 2019, tanggal 12 Maret 2019, tanggal 26 Maret 2019. Anak petak yaitu varietas Pena muti m'naes, Lamuru, dan Pioneer-36. Anak-anak petak yaitu 2 taraf penyiraman yang terdiri dari tidak disiram dan disiram. Hasil penelitian menunjukkan waktu tanam tanggal 12 Maret 2019 merupakan waktu tanam yang tepat dan sesuai dengan tingkat ketersediaan air dan radiasi matahari yang cukup dengan penggunaan yang lebih efisien dan tingkat intersepsi radiasi matahari yang lebih tinggi memberikan produksi jagung Pioneer-36 sebesar 8.47 ton ha-1 yang lebih baik dibandingkan produksi jagung varietas Lokal dan Lamuru pada waktu tanam lainnya. Hal tersebut didukung oleh adanya keselarasan tanggap kapasitas source (luas daun) dan kapasitas sink (ukuran tongkol).

Kata kunci:indeks luas daun, penyiraman, produksi, varietas

\section{PENDAHULUAN}

Tanaman jagung merupakan komoditas pangan nasional selain padi, gandum, kedelai dan sorgum. Sebagai

\footnotetext{
* Penulis untuk korespondensi. e-mail: syahya49@yahoo.co.id
}

bahan pangan, jagung memiliki nilai ekonomi yang strategis dalam meningkatkan ketahanan pangan. Di beberapa wilayah bagian Timur Indonesia seperti Nusa Tenggara Timur (NTT) dan Nusa Tenggara Barat (NTB), jagung masih difungsikan untuk bahan pangan hingga sekarang dan menjadi komoditas unggulan daerah. Tanaman jagung tergolong tanaman $\mathrm{C} 4$ yang efisien dalam memanfaatkan 
air dan tahan terhadap suhu tinggi sehingga cocok dibudidayakan di lahan kering dengan tingkat ketersediaan radiasi matahari yang memadai.

Pertumbuhan, perkembangan dan produksi tanaman merupakan suatu sistem yang sangat kompleks dan dipengaruhi oleh beberapa unsur iklim seperti radiasi matahari, suhu dan curah hujan (Indrawan et al., 2017). Radiasi matahari memiliki peran dalam proses pertumbuhan (morfogenesis), sedangkan air diperlukan dalam proses fotosintesis. Komponen-komponen faktor lingkungan tersebut secara tunggal maupun interaksi berpengaruh langsung terhadap pertumbuhan tanaman.

Tanggap tanaman terhadap faktor lingkungan berbedabeda tergantung jenis dan kultivar tanaman. Umumnya terdapat perbedaan morfologi antara varietas berumur panjang (hibrida dan komposit) dan varietas berumur pendek (genjah), antara lain tinggi tanaman, panjang dan lebar daun. Dalam penyesuaian pola tanam dan ketersediaan air, biasanya petani menggunakan varietas unggul berumur genjah. Perrin dan Mitchell (2013) menyatakan kekurangan cahaya akan menyebabkan perubahan morfo-fisiologi tanaman, seperti meningkatnya luas daun spesifik, panjang dan lebar daun, namun disisi lain intensitas cahaya rendah menurunkan rasio akar-tajuk dan total bahan kering tanaman (Akmali dan Suharyanto, 2017). Selain itu, intensitas radiasi yang tinggi akan mempercepat laju fotosintesis karena semakin banyak energi yang diterima daun, sehingga energi yang tersedia untuk mensintesis karbohidrat semakin banyak (Harrison et al., 2011).

Perubahan iklim (climate change) berpengaruh secara langsung terhadap siklus musim. Perubahan iklim mengakibatkan pergeseran waktu dan pola tanam, kerusakan tanaman dan penurunan produksi. Pengaruh waktu tanam, sesungguhnya berhubungan erat dengan tingkat ketersediaan unsur-unsur dari setiap faktor lingkungan tumbuh tanaman. Selain itu, tingkat ketersediaan unsur-unsur lingkungan tumbuh yang dibutuhkan bervariasi menurut fase pertumbuhan tanaman.

Dainty et al. (2016) menyatakan bahwa petani biasanya menetapkan waktu tanam berdasarkan kebiasaan turun temurun yaitu menunggu turunnya hujan. Runtunuwu et al. (2013) juga menunjukkan bahwa sebagian besar petani di wilayah Timur Indonesia melakukan penanaman untuk MT I, mulai akhir Januari sampai dengan awal Februari (Jan 111/Feb I) untuk penanaman padi ladang dan jagung terlebih dahulu dan pertengahan sampai akhir Februari (Feb 11/11l) untuk penanaman padi sawah. Menurut Dwiratna et al. (2016) bahwa jadwal tanam yang terbaik dapat dilakukan pada bulan Februari dasarian III (MT II).

Hambatan penanaman jagung di musim hujan adalah meningkatnya curah hujan (jenuh air), kurangnya radiasi matahari akibat banyaknya awan (mendung). Mubarak et al. (2018) menyatakan bahwa rendahnya radiasi yang sampai pada tanaman oleh penutupan awan saat musim hujan dapat menurunkan hasil tanaman. Penentuan waktu tanam dilakukan agar panjang musim tanam sesuai dengan kebutuhan tanaman dan menghindari kegagalan panen (Dwiratna et al., 2016). Penelitian ini bertujuan (1) menentukan waktu tanam yang efektif untuk mendapatkan radiasi dan air guna mencapai hasil panen yang optimal, (2) menentukan varietas yang sesuai dengan waktu tanam dan dapat menyelaraskan pemanfaatan radiasi dan air (3) mengetahui pengaruh penyiraman terhadap pertumbuhan dan hasil tanaman jagung.

\section{BAHAN DAN METODE}

Penelitian dilaksanakan di Balai Pengkajian Teknologi Pertanian(BPTP)Naibonat-NTT, padabulan Februari sampai Juli 2019. Percobaan disusun dalam bentuk rancangan splitsplit plot. Petak utama terdiri dari tiga waktu tanam yaitu tanggal 26 Februari 2019 (W1), tanggal 12 Maret 2019 (W2), tanggal 26 Maret 2019 (W3). Anak petak terdiri dari tiga varietas jagung yaitu varietas lokal (Pena muti m'naes) (V1), Lamuru (V2), dan Pioneer-36 (V3). Anak-anak petak yaitu 2 taraf penyiraman terdiri dari: tidak disiram (P0) dan disiram (P1). Terdapat 18 kombinasi perlakuan dan diulang sebanyak tiga kali sehingga terdapat 54 satuan percobaan.

Perlakuan penyiraman dilakukan sehari 1 kali mulai dari tanam hingga panen dan hanya pada petak yang diberi perlakuan penyiraman, sedangkan petak yang tidak disiram hanya memanfaatkan air dari curah hujan. Jumlah air yang diberikan sama dengan jumlah air yang hilang (evapotranspirasi potensial) pada tanaman jagung. Perhitungan evapotranspirasi potensial, diperoleh dari metode Thornthwaite dan Mather sebagai acuan dan dikoreksi dengan koefisien tanaman jagung. Setiap anakanak petak berukuran $3 \mathrm{~m} \times 2 \mathrm{~m}$, populasi tanaman per petak 40 tanaman. Sebelum benih ditanam, dilakukan seed treatment dengan insektisida berbahan aktif Tiametoksam, dosis yang digunakan adalah $3.5 \mathrm{~mL} \mathrm{~kg}^{-1}$ benih, kemudian benih jagung dikeringanginkan. Penanaman benih jagung dengan cara tugal sesuai perlakuan, jarak tanam yang digunakan adalah $75 \mathrm{~cm}$ x $20 \mathrm{~cm}, 2$ benih per lubang tanam kemudian diberi insektisida berbahan aktif karbofuran, selanjutnya dijarangkan pada 7 HST sehingga menyisahkan 1 tanaman per lubang tanam.

Pemupukan dilakukan dengan cara ditebar dalam larikan dangkal dengan jarak sekitar 5 sampai $7 \mathrm{~cm}$ dari batang tanaman. Dosis pupuk yang diberikan yaitu $300 \mathrm{~kg}$ Urea ha-1, $200 \mathrm{~kg} \mathrm{SP}-36 \mathrm{ha}^{-1}$ dan $50 \mathrm{~kg} \mathrm{KCL} \mathrm{ha-1}$. Pupuk Urea diberikan tiga kali yaitu $100 \mathrm{~kg}$ pada umur $10 \mathrm{HST}$, $150 \mathrm{~kg}$ umur $30 \mathrm{HST}$ dan $50 \mathrm{~kg}$ umur 45 HST. Penyulaman dilakukan apabila ada tanaman yang rusak atau mati.

Panen disesuaikan dengan umur panen setiap varietas jagung dengan ciri-ciri tongkol atau kelobot berwarna kekuningan atau mulai mengering, rambut tongkol berwarna coklat.

Peubah yang diamati adalah intersepsi radiasi matahari 45, 60, 75, dan 90 HST, indeks luas daun (ILD), umur berbunga $75 \%$, umur panen, lama periode berbunga hingga panen, komponen hasil dan produksi tanaman jagung. Pengukuran intensitas radiasi matahari pada tanaman jagung dengan menggunakan Lux meter. Pengukuran dilakukan dengan cara mengukur radiasi di atas dan di bawah tajuk tanaman jagung (Ariyanto et al., 2015) pada saat tanaman 
berumur 45, 60, 75, dan 90 HST. Persentase intersepsi radiasi matahari dapat dihitung dengan rumus:

$$
I=\frac{a-b}{a} \times 100 \%
$$

Di mana $\mathrm{I}=$ persentase intersepsi radiasi matahari (\%); a $=$ jumlah radiasi datang (di atas kanopi); dan $b=$ jumlah radiasi yang ditransmisikan di bawah kanopi.

Indeks luas daun dihitung sebagai perbandingan luas daun dengan luas tanam, perhitungan ILD dilakukan saat fase pembungaan (tassel). Pengumpulan data iklim berupa curah hujan, suhu udara, kelembaban, radiasi matahari, dan Evapotranspirasi diperoleh dari Stasiun Klimatologi Naibonat. Data hasil pengukuran ditabulasi dan diolah menggunakan sidik ragam (anova), apabila analisis ragam berpengaruh nyata dilanjutkan uji Duncan Multiple Range Tes dengan taraf 5\%, uji korelasi (nilai r) antar peubah. Software yang digunakan adalah SAS 9.4.

\section{HASIL DAN PEMBAHASAN}

\section{Intersepsi Radiasi Matahari}

Perbedaan waktu tanam memberikan pengaruh yang nyata terhadap intersepsi radiasi matahari tanaman jagung. Berdasarkan Gambar 1A, persentase intersepsi radiasi matahari pada waktu tanam yang berbeda mengalami fluktuasi pada semua umur tanaman. Intersepsi radiasi matahari tertinggi diperoleh pada penanaman tanggal 12 Maret 2019 saat tanaman berumur 75 HST sebesar 95.58\%. Sementara persentase intersepsi radiasi matahari terendah terdapat pada penanaman tanggal 26 Maret 2019 saat tanaman berumur 45 HST.

Sidik ragam menunjukkan perbedaan varietas jagung berpengaruh tidak nyata terhadap intersepsi radiasi matahari pada umur 45 dan 75 HST, tetapi saat pengamatan 60 dan 90 HST memberikan pengaruh yang nyata. Kurva persentase intersepsi radiasi matahari pada tiga varietas jagung (Gambar 1B) menunjukkan tanaman jagung varietas Pioneer-36 memiliki persentase intersepsi radiasi matahari tertinggi saat tanaman berumur 60, 75 dan 90 HST. Sementara tanaman jagung varietas Lokal memiliki persentase intersepsi radiasi matahari terendah pada semua umur tanaman.

Peubah intersepsi radiasi matahari 75 HST hanya perlakuan waktu tanam (26 Februari 2019, 12 Maret 2019, dan 26 Maret 2019) saja yang berpengaruh nyata terhadap intersepsi radiasi matahari, masing-masing memiliki nilai $94.69 \%$, 95.58\% dan $88.02 \%$ berturut-turut (Tabel 1). Hal ini disebabkan pada perlakuan waktu tanam 26 Februari dan 12 Maret menghasilkan tanaman dengan nilai ILD tinggi sehingga radiasi matahari yang diintersepsikan juga tinggi. Menurut Mubarak et al. (2018), intersepsi radiasi matahari yang tinggi dipengaruhi oleh ILD. Pada peubah intersepsi radiasi matahari 45 HST terjadi interaksi antara perlakuan varietas dengan penyiraman. Varietas Lamuru yang disiram memiliki persentase intersepsi radiasi matahari tertinggi yaitu $91.19 \%$, diikuti varietas Pioneer-36 yang tidak disiram yaitu $89.58 \%$, varietas Lamuru yang tidak disiram yaitu $89.24 \%$, dan varietas Lokal yang disiram yaitu 89.05\%. varietas Lokal yang tidak disiram dan varietas Pioneer-36 yang disiram memiliki persentase intersepsi radiasi matahari terendah yaitu $85.83 \%$ dan $87.89 \%$.

\section{Indeks Luas Daun (ILD)}

Analisis ragam menunjukkan perlakuan waktu tanam dan varietas berpengaruh nyata terhadap ILD. Penanaman jagung pada 26 Februari dan 12 Maret 2019 didukung oleh kondisi lingkungan yang cukup baik diantaranya curah hujan yang tinggi ditunjang dengan intensitas radiasi matahari yang tinggi juga, sehingga tanaman dapat memanfaatkan radiasi matahari untuk mengoptimalkan hasil fotosintesis. Nilai indeks luas daun tanaman jagung paling tinggi pada waktu tanam tanggal 26 Februari 2019 dan 12 Maret 2019 yaitu 3.85 , sedangkan nilai indeks luas daun terendah terdapat pada waktu tanam tanggal 26 Maret 2019 yaitu 2.90. Pada perlakuan varietas nilai indeks luas daun tertinggi terdapat pada varietas Pioneer-36 (3.85), diikuti varietas Lokal (3.58) dan varietas Lamuru (3.17) (Tabel 2). Hasil penelitian Belay
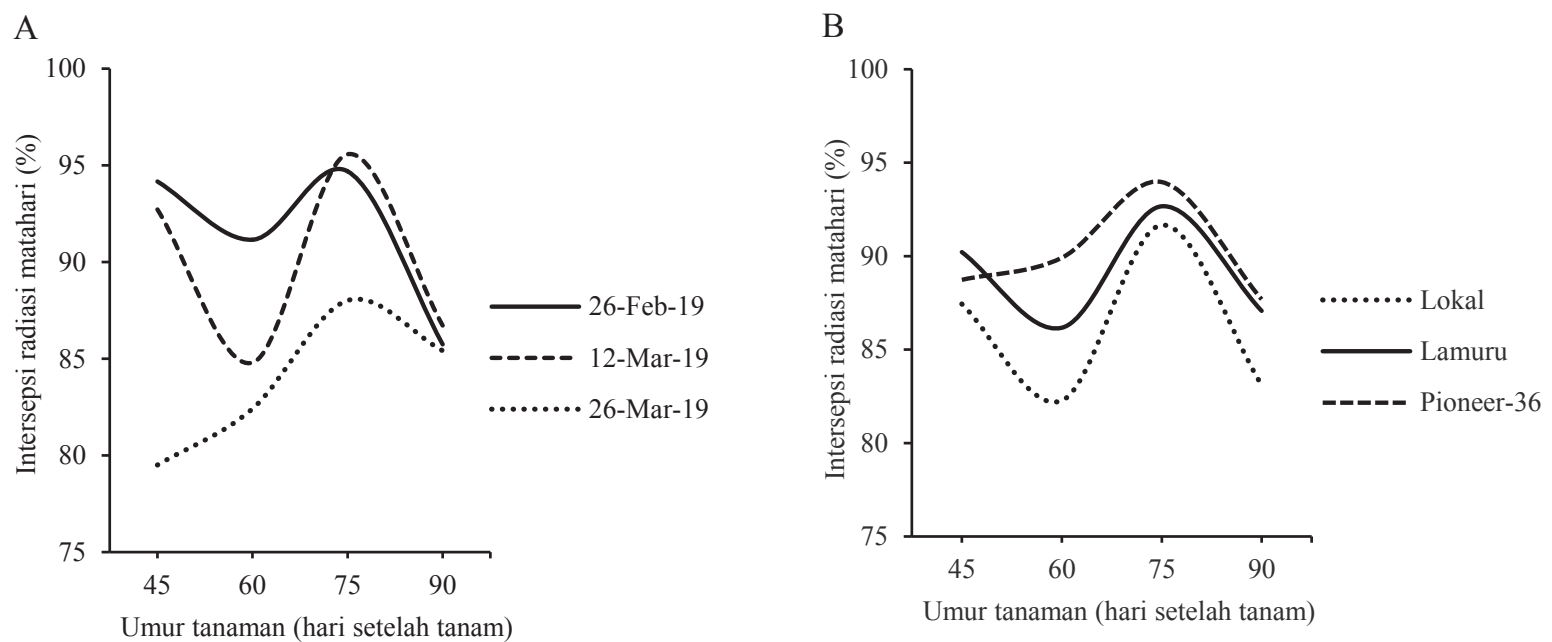

Gambar 1. Kurva intersepsi radiasi matahari pada perlakuan waktu tanam (A) dan varietas (B) 
Tabel 1. Tanggap intersepsi radiasi matahari pada umur tanaman jagung 75 HST terhadap waktu tanam, varietas dan penyiraman

\begin{tabular}{lc}
\hline Perlakuan & $\begin{array}{c}\text { Intersepsi radiasi matahari } \\
75 \text { HST }(\%)\end{array}$ \\
\hline Waktu tanam & $94.69 \mathrm{a}$ \\
26 Februari 2019 & $95.58 \mathrm{a}$ \\
12 Maret 2019 & $88.02 \mathrm{~b}$ \\
26 Maret 2019 & 92.76 \\
\hline Rerata & 91.66 \\
\hline Varietas & 92.67 \\
Lokal & 93.96 \\
Lamuru & 92.76 \\
Pionner-36 & \\
\hline Rerata & 92.35 \\
\hline Penyiraman & 93.17 \\
Tidak disiram & 92.76 \\
\hline Disiram & \\
\hline Rerata &
\end{tabular}

Keterangan: Angka yang diikuti huruf yang sama pada kolom yang sama menunjukkan tidak berbeda nyata pada uji DMRT $\alpha=5 \%$

dan Patil (2018) menunjukkan indeks luas daun dipengaruhi oleh waktu tanam dan varietas pada dua musim (2015 dan 2016) di India.

\section{Lama Periode Generatif}

Sidik ragam memperlihatkan bahwa varietas memiliki perbedaan nyata pada umur berbunga $75 \%$ dan umur panen serta lama periode berbunga hingga panen (Tabel 3). Tanggap umur berbunga $75 \%$, umur panen dan lama periode berbunga hingga panen nyata hanya terhadap perbedaan varietas. Hal ini disebabkan ketiga varietas yang diuji memiliki perbedaan umur berbunga, varietas Lamuru memiliki umur berbunga paling cepat dibandingkan dengan varietas Pioneer-36 dan varietas Lokal. Umur berbunga yang lama pada varietas Lokal dan Pioneer-36 dikarenakan umur tanaman (tanam hingga panen) lebih lama dari varietas Lamuru. Dengan demikian dapat dinyatakan bahwa ketiga varietas berbeda karena perbedaan genetik karakter umur tanaman. Hasil penelitian Khairiyah et al. (2017) bahwa varietas berpengaruh terhadap komponen pertumbuhan generatif hal ini disebabkan umur berbunga dan umur panen dipengaruhi oleh faktor genetik.

\section{Komponen Hasil}

Hasil penelitian menunjukkan bahwa perlakuan faktor tunggal waktu tanam tidak memberikan pengaruh yang nyata pada semua peubah, kecuali pada peubah bobot 100 biji. Perlakuan penyiraman nyata mempengaruhi jumlah baris per tongkol, jumlah biji per tongkol, dan bobot 100 biji (Tabel 4). Hal ini disebabkan tanaman yang mengalami cekaman kekeringan polen atau sel induk menjadi mandul sehingga kesuburan silk menjadi menurun dan mengakibatkan penurunan produksi biji bahkan gagal berproduksi.

Varietas berpengaruh nyata terhadap seluruh peubah komponen hasil. Varietas Pioneer-36 memiliki jumlah tongkol (1.03), jumlah baris per tongkol (14.27), jumlah biji per baris (31.34) tertinggi dibandingkan dengan varietas Lamuru dan varietas Lokal. Hal ini diduga varietas Pioneer36 memiliki nilai ILD yang tinggi sehingga cahaya yang diintersepsikan semakin tinggi. Intersepsi radiasi matahari yang tinggi memungkinkan pembentukan karbohidrat dan asimilat yang banyak untuk ditranslokasikan ke tongkol dan biji. Syafrudin et al. (2012) menyatakan bahwa jagung varietas hibrida memiliki hasil lebih tinggi daripada jagung varietas komposit (bersari bebas) karena varietas hibrida mempunyai gen-gen yang dominan dan mampu menghasilkan produksi tinggi.

Varietas Lokal menunjukkan bobot 100 biji paling berat yaitu $31.93 \mathrm{~g}$, diikuti varietas Lamuru sebasar 28.70 g dan varietas Pioneer-36 yaitu 26.76 g. Hal ini diduga tongkol yang dihasilkan ompong dan biji yang dihasilkan besar sehingga memiliki bobot 100 biji paling berat. Tongkol yang ompong disebabkan oleh terganggunya proses polinasi dan fertilisasi. Menurut Wulandari dan Batoro (2016) bahwa jagung Lokal putih memiliki ciriciri sebagai berikut tipe biji semi mutiara, warna biji putih, baris biji lurus dan memiliki bobot 1000 biji kurang lebih 313 g. Selain itu, Maharani et al. (2018) juga menyatakan bahwa pengamatan bobot 100 biji yang tinggi menandakan besarnya endosperm dalam biji. Bobot 100 biji menurun

Tabel 2. Tanggap indeks luas daun jagung terhadap perlakuan waktu tanam, varietas dan penyiraman

\begin{tabular}{ll}
\hline Perlakuan & Indeks luas daun \\
\hline Waktu tanam & \\
26 Februari 2019 & $3.85 \mathrm{a}$ \\
12 Maret 2019 & $3.85 \mathrm{a}$ \\
26 Maret 2019 & $2.90 \mathrm{~b}$ \\
\hline Rerata & 3.53 \\
\hline Varietas & \\
Lokal & $3.58 \mathrm{~b}$ \\
Lamuru & $3.17 \mathrm{c}$ \\
Pioneer-36 & $3.85 \mathrm{a}$ \\
\hline Rerata & 3.53 \\
\hline Penyiraman & \\
Tidak disiram & 3.44 \\
Disiram & 3.63 \\
\hline Rerata & 3.50 \\
\hline
\end{tabular}

Keterangan: Angka yang diikuti huruf yang sama pada kolom yang sama menunjukkan tidak berbeda nyata pada uji DMRT $\alpha=5 \%$ 
Tabel 3. Tanggap umur berbunga 75\%, umur panen dan lama periode berbunga hingga panen terhadap perlakuan waktu tanam, varietas dan penyiraman jagung

\begin{tabular}{|c|c|c|c|}
\hline Perlakuan & Umur berbunga $75 \%$ & Umur panen & Lama periode berbunga hingga panen \\
\hline \multicolumn{4}{|l|}{ Waktu tanam } \\
\hline 26 Februari 2019 & 54.28 & 100 & 45.72 \\
\hline 12 Maret 2019 & 54.17 & 100 & 45.83 \\
\hline 26 Maret 2019 & 54.39 & 100 & 45.61 \\
\hline Rerata & 54.28 & 100 & 45.72 \\
\hline \multicolumn{4}{|l|}{ Varietas } \\
\hline Lokal & $55.11 \mathrm{a}$ & $105 \mathrm{a}$ & $49.89 \mathrm{a}$ \\
\hline Lamuru & $53.39 \mathrm{c}$ & $95 \mathrm{c}$ & $41.61 \mathrm{c}$ \\
\hline Pionner-36 & $54.33 b$ & $100 \mathrm{~b}$ & $45.67 \mathrm{~b}$ \\
\hline Rerata & 54.28 & 100 & 45.72 \\
\hline \multicolumn{4}{|l|}{ Penyiraman } \\
\hline Tidak disiram & 54.37 & 100 & 45.63 \\
\hline Disiram & 54.19 & 100 & 45.81 \\
\hline Rerata & 54.28 & 100 & 45.72 \\
\hline
\end{tabular}

Keterangan: Angka yang diikuti huruf yang sama pada kolom yang sama menunjukkan tidak berbeda nyata pada uji DMRT $\alpha=5 \%$

Tabel 4. Tanggap jumlah tongkol per tanaman, jumlah baris per tongkol, jumlah biji per baris dan jumlah biji per tongkol terhadap perlakuan waktu tanam, varietas dan penyiraman jagung

\begin{tabular}{lccccc}
\hline Perlakuan & $\begin{array}{c}\text { Jumlah tongkol } \\
\text { per tanaman }\end{array}$ & $\begin{array}{c}\text { Jumlah baris per } \\
\text { tongkol }\end{array}$ & $\begin{array}{c}\text { Jumlah biji per } \\
\text { baris }\end{array}$ & $\begin{array}{c}\text { Jumlah biji per } \\
\text { tongkol }\end{array}$ & $\begin{array}{c}\text { Bobot 100 biji } \\
(\mathrm{g})\end{array}$ \\
\hline Waktu tanam & & & & & \\
26 Februari 2019 & 1.02 & 12.80 & 20.15 & 274.41 & $28.09 \mathrm{~b}$ \\
12 Maret 2019 & 1.02 & 13.58 & 23.93 & 333.21 & $30.14 \mathrm{a}$ \\
26 Maret 2019 & 1.01 & 11.71 & 19.03 & 240.70 & $29.16 \mathrm{ab}$ \\
\hline Rerata & 1.01 & 12.70 & 21.04 & 282.77 & 29.13 \\
\hline Varietas & & & & & \\
$\quad$ Lokal & $1.00 \mathrm{~b}$ & $10.95 \mathrm{c}$ & $11.94 \mathrm{c}$ & $135.84 \mathrm{c}$ & $31.93 \mathrm{a}$ \\
Lamuru & $1.01 \mathrm{~b}$ & $12.87 \mathrm{~b}$ & $19.83 \mathrm{~b}$ & $265.18 \mathrm{~b}$ & $28.7 \mathrm{~b}$ \\
$\quad$ Pioneer-36 & $1.03 \mathrm{a}$ & $14.27 \mathrm{a}$ & $31.34 \mathrm{a}$ & $447.29 \mathrm{a}$ & $26.76 \mathrm{c}$ \\
\hline Rerata & 1.01 & 12.70 & 21.04 & 282.77 & 29.13 \\
\hline Penyiraman & & & & \\
$\quad$ Tidak disiram & 1.01 & $12.47 \mathrm{~b}$ & 20.16 & $267.66 \mathrm{~b}$ & $28.46 \mathrm{~b}$ \\
Disiram & 1.01 & $12.92 \mathrm{a}$ & 21.91 & $297.88 \mathrm{a}$ & $29.80 \mathrm{a}$ \\
\hline Rerata & 1.01 & 12.70 & 21.04 & 282.77 & 29.13 \\
\hline
\end{tabular}

Keterangan: Angka yang diikuti huruf yang sama pada kolom yang sama menunjukkan tidak berbeda nyata pada uji DMRT $\alpha=5 \%$

apabila mengalami kekeringan, tanaman yang tidak disiram memiliki bobot 100 biji lebih ringan (28.46 g) dibandingkan dengan tanaman yang disiram $(29.80 \mathrm{~g})$. Hasil penelitian ini sejalan dengan penelitian dari Wulansyah et al. (2017).

\section{Produksi}

Sidik ragam menunjukkan bahwa waktu tanam, varietas, penyiraman dan interaksi waktu tanam $\mathrm{x}$ varietas, waktu tanam $\mathrm{x}$ penyiraman, varietas $\mathrm{x}$ penyiraman serta 
interaksi antara waktu tanam, varietas dan penyiraman berpengaruh nyata terhadap produksi.

Jagung varietas Pioneer-36 yang ditanam pada tanggal 12 Maret 2019 dan 26 Februari 2019 yang disiram memiliki produksi tertinggi yaitu 8.47 ton $\mathrm{ha}^{-1}$ dan 7.78 ton $\mathrm{ha}^{-1}$ dari perlakuan lainnya. Sementara jagung varietas Lokal yang ditanam pada tanggal 26 Maret 2019 baik yang disiram maupun tidak disiram memiliki produksi paling rendah yaitu 0.34 dan 0.46 ton ha $^{-1}$ (Tabel 5). Hal ini diduga pada varietas Pioneer-36 yang di tanam pada tanggal 26 Februari dan 12 Maret memiliki ketersediaan air (curah hujan tinggi) dan intersepsi radiasi matahari yang tinggi sehingga proses fotosintesis untuk pembentukan asimilat berjalan dengan baik dan juga didukung oleh karakter komponen hasil yang tinggi sehingga produksi biji yang di hasilkan juga tinggi. Menurut Pratama et al. (2019) karakter komponen hasil memberikan kontribusi yang besar terhadap kemampuan menghasilkan biji pipilan.

Tanggap terhadap perlakuan penyiraman (peningkatan hasil), varietas Lamuru paling tanggap pada waktu tanam tanggal 26 Maret 2019 (143.75\%), diikuti waktu tanam tanggal 26 Februari 2019 (59.57\%) dan varietas Pioneer36 pada waktu tanam 12 Maret 2019 (58.75\%) serta varietas Lokal yang ditanam pada tanggal 12 Maret 2019. Sementara varietas Lamuru yang ditanam pada tanggal 12 Maret 2019 kurang tanggap terhadap perlakuan penyiraman yaitu 20.34\%, diikuti varietas Pioneer-36 pada waktu tanam26 Maret 2019 sebesar 29.23\%, Varietas Pioneer-36 pada waktu tanam 26 Februari 2019 yaitu 34.62\%, Varietas Lokal pada waktu tanam 26 Maret 2019 sebesar 35.62\% dan varietas Lokal pada waktu tanam 26 Februari 2019 sebesar $37.50 \%$.

\section{Pembahasan Umum}

Perbedaan waktu tanam memperlihatkan kondisi lingkungan yang berbeda pada pertumbuhan dan hasil tanaman jagung, sehingga menghasilkan produksi jagung yang berbeda pula. Penentuan waktu tanam yang tepat dan sesuai dengan kondisi lingkungan setempat akan menghasilkan produksi yang tinggi. Selain itu, penggunaan varietas yang tepat juga dapat meningkatkan produksi.

Intersepsi radiasi matahari merupakan selisih antara radiasi datang dengan yang ditransmisikan (yang diteruskan sampai di bawah tajuk tanaman). Berdasarkan Gambar 1a diketahui bahwa tanaman dengan waktu tanam 26 Februari dan 12 Maret 2019 mengintersepsi radiasi lebih banyak dibandingkan dengan yang waktu tanam tanggal 26 Maret 2019. Intersepsi radiasi sangat dipengaruhi oleh struktur kanopi tanaman melalui ILD dan koefisien pemadaman tajuk.

Sebagian radiasi matahari yang sampai ke permukaan daun pada awal pertumbuhan dimanfaatkan untuk menambah luas daun (source). Bertambahnya luas daun akan meningkatkan penyerapan energi matahari oleh daun untuk pembentukan sink. Sementara itu, pada tanaman jagung yang ditanam pada tanggal 26 Maret 2019 mempunyai ILD yang rendah disebabkan karena pengguguran dan penyempitan daun, serta banyak terjadi penutupan awan (mendung) tetapi tidak sampai turun hujan. Keadaan tersebut berdampak pada rendahnya radiasi yang sampai ke permukaan yang mampu diserap oleh tanaman. Defisit radiasi akan mengganggu keserasian antara source dan sink. Selain dipengaruhi oleh radiasi matahari juga dipengaruhi oleh air (curah hujan). Anjum et al. (2011) mengemukakan bahwa cekaman air secara langsung berdampak pada laju fotosintesis. Hal ini sebagai akibat menutupnya stomata dan meningkatnya resistensi mesofil yang akhirnya memperkecil hasil fotosintesis.

Tabel 6 menunjukkan uji korelasi intersepsi radiasi 75 HST dengan ILD dan produksi berdasarkan waktu tanam pada masing-masing varietas. Intersepsi radiasi matahari berkorelasi positif sangat nyata dengan ILD dan produksi. Semakin tinggi nilai ILD maka radiasi yang diintersepsikan akan semakin banyak dan produksi tanaman jagung semakin tinggi. Nilai korelasi tersebut dengan tingkat yang berbeda

Tabel 5. Tanggap peubah bobot kering biji beberapa varietas jagung terhadap perlakuan waktu tanam dan penyiraman

\begin{tabular}{|c|c|c|c|c|}
\hline \multirow{2}{*}{ Perlakuan } & & \multicolumn{2}{|c|}{ Penyiraman } & \multirow{2}{*}{ Peningkatan hasil (\%) } \\
\hline & & Tidak disiram & Disiram & \\
\hline Waktu tanam & Varietas & \multicolumn{2}{|c|}{ 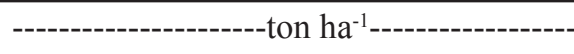 } & \\
\hline \multirow[t]{3}{*}{26 Februari 2019} & Lokal & $0.89 \mathrm{jk}$ & $1.22 \mathrm{jk}$ & 37.50 \\
\hline & Lamuru & $2.61 \mathrm{gh}$ & $4.17 \mathrm{de}$ & 59.57 \\
\hline & Pionner-36 & $5.78 b$ & $7.78 \mathrm{a}$ & 34.62 \\
\hline \multirow[t]{3}{*}{12 Maret 2019} & Lokal & $1.11 \mathrm{jk}$ & $1.58 \mathrm{ij}$ & 42.50 \\
\hline & Lamuru & $3.22 \mathrm{fg}$ & $3.88 \mathrm{def}$ & 20.34 \\
\hline & Pionner-36 & $5.33 \mathrm{bc}$ & $8.47 \mathrm{a}$ & 58.75 \\
\hline \multirow[t]{3}{*}{26 Maret 2019} & Lokal & $0.34 \mathrm{k}$ & $0.46 \mathrm{k}$ & 35.62 \\
\hline & Lamuru & $0.89 \mathrm{jk}$ & $2.17 \mathrm{hi}$ & 143.75 \\
\hline & Pionner-36 & $3.61 \mathrm{ef}$ & $4.67 \mathrm{~cd}$ & 29.23 \\
\hline
\end{tabular}

Keterangan: Angka yang diikuti huruf yang sama pada kolom yang sama menunjukkan tidak berbeda nyata pada uji DMRT $\alpha=5 \%$ 
Tabel 6. Hasil uji korelasi intersepsi radiasi matahari 75 HST dengan ILD dan produksi dari tanaman jagung berdasarkan waktu tanam pada masingmasing varietas

\begin{tabular}{lcc}
\hline Peubah & $\begin{array}{c}\text { Intersepsi radiasi } \\
\text { matahari 75 HST }\end{array}$ & ILD \\
\hline Varietas lokal & $0.606^{* *}$ & \\
$\quad$ ILD & $0.715^{* *}$ & $0.473^{*}$ \\
$\quad$ Produksi & & \\
Varietas Lamuru & $0.857^{* *}$ & \\
ILD & $0.834^{* *}$ & $0.884^{* *}$ \\
$\quad$ Produksi & & \\
Varietas Pioneer-36 & $0.747^{* *}$ & \\
$\quad$ ILD & $0.591^{*}$ & $0.860^{* *}$ \\
Produksi &
\end{tabular}

Keterangan: ILD = indeks luas daun; HST = hari setelah tanam; $*$ = nyata pada taraf $\alpha=5 \% ; * *=$ sangat nyata pada $\operatorname{taraf} \alpha=1 \%$

antar varietas. Hal ini kemungkinan disebabkan varietas yang berbeda memiliki efisiensi penggunaan radiasi yang berbeda. Hal tersebut disebabkan oleh kemampuan mengintersepsi dan mengubah radiasi matahari ke bobot kering juga berbeda.

Jumlah tongkol per tanaman, jumlah baris per tongkol, jumlah biji per baris, dan jumlah biji per tongkol memiliki korelasi positif dengan produksi, masing-masing memiliki nilai $0.580,0.742,0.854,0.874$ berturut-turut. Hal ini menunjukkan apabila peubah komponen hasil di atas memiliki nilai yang tinggi, maka produksi tanaman jagung juga semakin tinggi. Tingkat produksi ditentukan oleh $85 \%$ atau lebih dari ukuran atau kapasitas sink (ukuran tongkol). Pada perlakuan waktu tanam tanggal 12 Maret 2019 dengan varietas Pioneer-36 yang disiram dan tidak disiram cenderung memiliki nilai yang paling baik pada peubah komponen hasil dan produksi tanaman jagung.

\section{KESIMPULAN}

Waktu tanam tanggal 12 Maret 2019 di Nusa Tenggara Timur merupakan waktu tanam yang tepat dan sesuai dengan tingkat ketersediaan radiasi matahari dan air sehingga memberikan produksi jagung Pioneer-36 sebesar 8.47 ton ha $^{-1}$ yang lebih baik dibandingkan produksi jagung Lokal dan Lamuru pada waktu tanam lainnya. Jagung varietas Pioneer-36 yang ditanam pada tanggal 12 Maret 2019 menunjukkan pertumbuhan dan hasil tertinggi daripada varietas lainnya. Penanaman jagung varietas Pioneer-36 pada tanggal 12 Maret 2019 dengan ketersediaan air dan radiasi dengan penggunaan yang lebih efisien dan tingkat intersepsi yang lebih tinggi menghasilkan produksi tertinggi yaitu 8.47 . Hal tersebut didukung oleh adanya keselarasan tanggap kapasitas source (luas daun) dan kapasitas sink (ukuran tongkol).

\section{DAFTAR PUSTAKA}

Akmali, H.A., E. Suharyanto. 2017. Pengaruh perbedaan intensitas cahaya dan penyiraman pada pertumbuhan jagung (Zea mays L.) 'Sweet Boy-02'. J. Sain Dasar. 6:8-16.

Anjum, S.A., X. Xie, L. Wang, M.F. Saleem, C. Man, W. Laei. 2011. Morphological, physiological and biochemical responses of plants to drought stress. Afr. J. Agric. Res. 6:2026-2032.

Ariyanto, A., M.S. Hadi, M. Kamal. 2015. Kajian intersepsi cahaya matahari pada tiga varietas sorgum (Sorghum bicolor L.) dengan kerapatan tanaman berbeda pada sistem tumpangsari dengan ubi kayu (Manihot esculenta Crantz). J. Agrotek Tropik. 3:355-361.

Belay, A.T., R.H. Patil. 2018. Response of maize hybrids to sowing dates in Northern Trazitional Zone of Karnataka. Int. J. Pure App. Biosci. 6:71-84.

Dainty, I., S.H. Abdullah, A. Priyati. 2016. Analisis peluang curah hujan untuk penetapan pola dan waktu tanam serta pemilihan jenis komoditi yang sesuai di Desa Masbagik Kecamatan Masbagik Kabupaten Lombok Timur. J. Ilmiah Rekayasa Pertanian dan Biosistem 4:207-216.

Dwiratna, S.N.P., E. Suryadi, K.D. Kamaratih. 2016. Optimasi pola tanam pada lahan sawah tadah hujan di Kecmatan Cimanggung Kabupaten Sumedang. J. Teknotan. 10:37-45.

Harrison, L., J. Michaelsen, C. Funk, G. Husak. 2011. Effects of temperature changes on maize production in Mozambique. Climate Research 46:211-222.

Indrawan, R.R., A. Suryanto, R. Soeslistyono. 2017. Kajian iklim mikro terhadap berbagai sistem tanam dan populasi tanaman jagung manis (Zea mays saccharata Sturt.). J. Produksi Tanaman 5:92-99.

Khairiyah, S. Khadijah, M. Iqbal, S. Erwan, Norlian, Mahdiannoor. 2017. Pertumbuhan dan hasil tiga varietas jagung manis (Zea mays saccharata Sturt.) terhadap berbagai dosis pupuk organik hayati pada lahan rawa lebak. Ziraa'ah 42:230-240.

Maharani, P.D., A. Yunus, D. Harjoko. 2018. Jarak tanam berbeda pada uji daya hasil lima varietas jagung hibrida. J. Agrotech. Res. 2:52-57. 
Mubarak, S., Impron, T. June. 2018. Efisiensi penggunaan radiasi matahari dan respon tanaman kedelai (Glycine $\max$ L.) terhadap penggunaan mulsa reflektif. J. Agron. Indonesia 46:247-253.

Perrin, P.M., F.J.G. Mitchell. 2013. Effects of shade on growth, biomass allocation and leaf morphology in European yew (Taxus baccata L.). Eur. J. For. Res. 132:211-218.

Pratama, E.Y., R. Hasputri, B. Sutrisno, R.T. Setiyono. 2019. Uji daya hasil pada beberapa calon varietas jagung hibrida. J. Pertanian Presisi 3:120-128.
Runtunuwu, E., H. Syahbuddin, F. Ramadhani, Y. Apriyana, K. Sari, W.T. Nugroho. 2013. Tinjauan waktu tanam tanaman pangan di wilayah Timur Indonesia. J. Pangan 22:1-10.

Wulandari, F., J. Batoro. 2016. Etnobotani jagung (Zea maize L.) pada masyarakat lokal di Desa Pandan Sari Kecamatan Pancokusumo Kabupaten Malang. J. Biotropika. 4:17-24.

Wulansyah, U.T., A.R. Amin, M.B.D.R. Farid. 2017. Ketahanan beberapa genotipe jagung (Zea mays L.) sintetik-2 terhadap cekaman kekeringan. J. Agrotan. 3:32-55. 